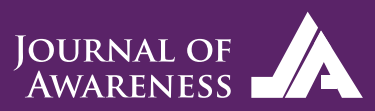

8
Journal of Awareness

Volume / Cilt: 6, Issue / Sayl:4, 2021, pp. 269-278

E-ISSN: 2149-6544

https://journals.gen.tr/joa

DOI: https://doi.org/10.26809/joa.6.4.07
Received / Geliș: 22.09.2021 Accepted / Kabul: 27.10 .2021

\title{
Eğitim kurumlarında çalışanların stresle başa çıkma yöntemleri ile sigara bağımlılığ 1 arasındaki ilişki
}

\author{
The relationship between methods of coating with stress and \\ smoking addiction of the employees in educational institutions
}

\section{Ayşegül Arasıl}

Bağımsız araştırmacı, Türkiye, e-mail: arasilaysegul@gmail.com

Öz

Bu çalışmanın amacı eğitim kurumlarında çalışanların stresle başa çıkma yöntemleri ile sigara bağımlılığı arasındaki ilişkinin incelenmesi ve bu ölçeklerin demografik özellikler açısından nasıl farklılaştığının araştırılmasıdır. Araştırmanın evreni İstanbul ilinde ikamet eden ve araştırmaya katılmayı gönüllü olarak kabul eden 18- 65 yaş aralığındaki sigara içen kişilerden oluşmaktadır. Katılımcılar seçilirken olasılıksız örnekleme yöntemlerinden olan uygun örneklemeden yararlanılmıştır. Araştırmada Kişisel Bilgi Formu, Stresle Başa Çıkma Tarzları Envanteri ve Fagerström Nikotin Bağımlılık Testi kullanılmıştır. Veriler, SPSS 25.0 istatistik programı ile analiz edilmiştir. Araştırmada stresle başa çıkma tarzları envanteri ve alt boyut puanlarına göre, cinsiyet, yaş, eğitim ve gelir değişkeni açısından anlamlı farklılıklar bulunmuştur. Fagerström Nikotin Bağımlılık Testi alınan puanların cinsiyet, gelir, eğitim ve yaş değişkeni açısından anlamlı farklılıklar bulunmuştur. Stresle Başa Çıkma Tarzları Envanteri ve alt boyutları Kendine Güvenli Yaklaşım, İyimser Yaklaşım ve Çaresiz Yaklaşım ile Fagerström Nikotin Bağımlılık Testi puanları arasında istatistiksel olarak negatif yönde anlamlı ilişki olduğu belirlenmiştir. Sosyo demografik özelliklere göre katılımcıların stresle başa çıkma yöntemleri ve sigara bağımlılığı puanlarının farklılaştığı bulunmuştur.

Genel sonuçlar doğrultusunda stresle başa çıkma tarzları envanteri ve alt boyutları kendine güvenli yaklaşım, iyimser yaklaşım ve çaresiz yaklaşım özellikleri ile stresle başa çıkma becerilerinin geliştirilmesine yönelik bilgilendirme ve eğitim düzenlenmesi önerilir.

Anahtar kelimeler: Stres, stresle başa çıkma tarzları, sigara, nikotin 


\begin{abstract}
The aim of this research is to examine the relationship between methods of coping with stress and smoking addiction of the employees in educational institutions and to investigate how these scales differ in terms of demographic characteristics. The population of the research consists of smokers between the ages of 18-65 who reside in Istanbul and voluntarily agree to participate in our research. While selecting the participants, convenient sampling, which is one of the non-probability sampling methods, was used. Personal Information Form, Coping Styles Inventory and Fagerström Nicotine Dependence Test were used in the study. The data were analyzed with the SPSS 25.0 statistical program. In the study, significant differences were found in terms of gender, age, education and income variables, according to the scores obtained from the inventory of coping styles and sub-dimensions. Significant differences were found in the Fagerström Test for Nicotine Addiction scores in terms of gender, income, education and age. It has been determined that there is a statistically significant negative correlation between the Stress Coping Styles Inventory and its sub-dimensions, SelfConfident Approach, Optimistic Approach, Helpless Approach, and Fagerström Nicotine Dependence Test scores. It was found that the methods of coping with stress and cigarette addiction scores of the participants differed according to their sociodemographic characteristics.
\end{abstract}

In the general results, it is recommended to organize information and training to improve coping skills with stress coping styles inventory and its sub-dimensions, self-confident approach, optimistic approach and helpless approach.

Keywords: Stress, stress coping styles, smoking, nicotin

\section{GÍRIŞ}

İnsanlar hayatlarının her anında birçok fiziksel ve zihinsel uyaranla karşı karşıya kalırlar ve bu uyaranlar kişinin denge ve uyum durumunu etkileyebilir. Olay sıkıntı vericiyse, yeniden ayar gerektiriyorsa, alıştığ1 yaşam biçimini ve çözümü sorgular veya değiştirirse, kişi bu zor olayı atlatmaya ve tekrar rahatlamaya ve uyum sağlamaya çalışacaktır Özarslan ve diğ.(2013). Bu noktada stres ve başa çıkma kavramları önem kazanmaktadır (Werden, 2001).

Selye (1974), stresi bir kişinin etkilerine karşı spesifik olmayan bir tepki olarak tanımlamıştır. Daha sonra bu tanıma zaman kavramını da dahil ederek genel uyum sendromu olarak adlandırmıştır. Genel uyum sendromu, bir kişinin strese verdiği tepkidir ve meydana gelen spesifik olmayan tüm değişiklikleri içerir. Ek olarak, stresörler vücudun çeşitli kısımlarını etkilediğinden, Selye savunma tepkisine genel bir isim vermiştir. Adaptasyon, vücudun strese karşı savaşmasına veya uyum sağlamasına yardımcı olmak için tasarlanmış savunma mekanizmalarıdır. Sendrom ayrıca, bireysel yanıt bölümlerinin az ya da çok birlikte meydana geldiğini gösterir Ivancevich ve Matteson (1990).

Genel uyum sendromuna göre, alarm, direnç ve tükenme aşamalarında vücut strese karşı tepki verir. Alarm aşamasında, dış uyaran stres olarak algılanır.
Alarm aşamasında dış uyaranlara karşı bazı bedensel değişiklikler görülebilir. Biyokimyasal reaksiyonları aktive ederek vücut kendini korumaya çalışır. Artan nefes alma, kan basıncının artması, kasların gerilmesi gibi belirtiler sonucunda kafa karışıklığı, uyumsuzluk, gerçeğin çarpıtılması belirtileri görülebilir ve dayanma gücü azalabilir. Direnç aşamasında, vücut bozulan dengeyi sağlamaya çalışır ve bu dengeyi sağlamak için ruhsal ve bedensel enerji harcar. Direnç evresinde aş1r1 yorgunluk, anksiyete, gerginlik ve sinirlilik görülür. Direnç aşamasında kişi stresörle savaşır Ivancevich ve Matteson (1990). Kişi başarılı olursa stresin bedensel belirtileri iyileşir. Ancak stresörler ortadan kalkmazsa ve etkili olmaya devam ederse, tükenme aşamasına girerler. Direnç aşamasında vücut her türlü ruhsal ve bedensel rahatsızlığa açık hale gelir. Selye'ye (1974) göre stresin süregelmesi vücutta yıpranmaya neden olur. Vücudun savunması streslere dayanabiliyorsa, genel uyum işareti iyi çalışıyor demektir.

Stres ile ilgili ilk çalışmalar tıp alanında başlamış ve stresli yaşam olaylarının çeşitli davranışsal ve psikolojik sorunların ortaya çıkmasında ve devam etmesinde etkili bir neden olarak tartışılmasıyla birlikte birçok araştırmacı konuya ilgi göstermiş ve farklı tanımlamalar yapılmıştır. Folkman ve Lazarus tarafından geliştirilen tanıma göre stres, kaynakları aşan veya zorlayan ve/veya barışı veya genel refahı değerlendiren "kişi-çevre etkileşimi" sonucunda yaşanır (Folkman ve Lazarus, 1986: 571). Başa çıkma, kişinin iç ve dış 
dünyanın yarattığı ihtiyaç ve güçlükleri karşılama, kontrol altında tutma ve gerilimleri azaltmaya yönelik bilişsel ve davranışsal çabalarıdır (Basut, 2006: 36).

Başa çıkmanın iki temel işlevi vardır. Birincisi, sorunun ana kaynağına ilişkin başa çıkma tutumlarını kullanarak strese neden olan problemlerle başa çıkmayı sağlayan "problem temelli başa çıkma", ikincisi ise ana kaynağın yol açtı ̆̆ duygusal etkiyle başa çıkma tutumlarını içeren "duygusal temelli başa çıkmadır" (Kraaij ve diğ. 2002: 163).

Tütün, dünyada bağımlılık yapan maddelerin en başında gelir. Tütün bağımlılığından kurtulan kişilerin çoğu kısa sürede tekrar başlama eğilimindedir. Bu, tütünün bağımlılık yapma gücünü kanıtlamaktadır. Tütünün içindeki diğer önemli maddeler karbon, nikotin ve katrandır Bal (2019). Sigarayı birakamayan bağımlıların önemli bir kısmı stres ile mücadele edemediklerini gerekçe olarak öne sürer. Yine sigarayı bırakmayı denemelerine rağmen tekrar başlayanların da büyük çoğunluğu benzer sebepleri ileri sürmektedir. Stres vücudun asit üretmesini, asit ise nikotin eksikliğinin ortaya çıkmasını sağlar, bu durum nikotin yoksunluğu semptomlarının ortaya çıkmasına sebep olur. Bu döngü sonucunda en sık anksiyete, tedirginlik ve keyifsizlik ile karşılaşılır. Sigara kullanımı hem beyne hem de davranışlara etki eden bir hastalıktır. Sigara bağımlılı̆̆ı; nörobiyolojik, psikolojik, çevresel ve genetik gibi faktörlerin oluşturduğu karmaşık davranışsal bir yansımadır. Dünya Sağlık Örgütü (DSÖ)' ne göre, günde bir defa veya daha fazla sigara içiliyor olması düzenli içicilik anlamına gelmektedir. Gün aşırı sigara içmeyen kişiler düzensiz içici olarak adlandırılmaktadır. Nikotin sigarada bağımlılığa neden olan ana bileşendir. Nikotin, bağımlılığa neden olan diğer bazı maddeler gibi beyinde bulunan haz ve ödül merkezine etki ederek kişide bağımlılığın gelişmesine sebebiyet verir. Bağımlılı̆̆a sebep olan maddenin, yarı ömrü ne kadar kısa olursa kişide bağımlılık da o denli hızlı bir gelişim gösterir Keten ve diğ. (2014: 58).

Dünya Sağlık Örgütü (WHO)'nün sonuçlarına göre her yıl yaklaşık 4,5 milyon kişi sigara kullanımı sebepli rahatsızlıklar nedeniyle hayatını kaybetmektedir. Önümüzdeki yıllarda bu sayının çok artacağı ve sigara sebepli ölümlerin çoğunun gelişmekte olan ve az gelişmiş ülkelerde gerçekleşeceği öngörülmektedir. Sigara içme durumunun çok yaygın olduğu ülkemizde sigaranın neden olduğu akciğer kanseri ve (KOAH) gibi hastalıklar önemli sağlık sorunları teşkil etmektedir Demir ve diğ. (2004: 63).

\section{ARASTIRMANIN EVREN VE ÖRNEK- LEMİ}

Araştırmanın evreni İstanbul ili'nde ikamet eden kişiler, örneklem ise araştırmaya katılmayı gönüllü olarak kabul eden 18- 65 yaş aralığındaki sigara içen 212 kişidir.

\section{KURAMSAL ÇERÇEVE VE İLGİLİ Lİ- TERATÜR}

\subsection{Stres tanımı}

Hans Selye (1976) stresle ilgili ilk çalışmaları yapan kişi olarak stres için, bedende fizyolojik tepkiler meydana getirdiğini ve iki tür stres olduğunu belirtmektedir. Birincisi; yararlı stres (eustress) kişilerin hayatındaki değişikliklere uyum sağlamasını kolaylaştırıp, performansının yükselmesini sağlar. İkincisi ise; zararlı stres (distres) aşırı baskı nedeniyle etkinliğin kaybedilmesine, sağlığın olumsuz yönde etkilenmesine ve çöküntüye neden olabilen strestir Froyen (1988).

Genel olarak stres "sıkıntı" veya "zorluk" anlaminda kullanılmaktadır Graham (1999). Bu tanımlara ilaveten, farklı yaklaşımlarla stres kavramını çeşitli şekillerde ifade eden tanımlamalar görülmektedir. Schermeron (1989)' a göre stres, kişinin olağanüstü istekler, kısıtlamalar veya fırsatlarla karşılaştığında yaşadığı bir baskı hali olarak tanımlar. Bir diğer tanıma göre; "Stres, kişinin fiziksel ve sosyal çevresinden gelen uyumsuz koşullar nedeniyle fiziksel ve psikolojik sınırlarının ötesinde harcadığı çaba olarak tanımlanmaktadır".

\subsection{Stres belirtileri}

Strese yönelik verilen tepkiler ve stres tetikleyicileri farklı olsa da benzer bedensel semptomlar gözlenebilir. Bunlara örnekler şu şekildedir Gökler (2012: 154); Öfkeli hal, depresyon veya yüksek heyecan, çarpıntı, yüksek tansiyon belirtisi, boğaz ve ağı kuruluğu, çalışmaya odaklanamama, karışıklık, sinir tikleri, en ufak seste irkilme eğilimi, yüksek perdeden sinirli kahkaha, kekemelik ve konuşma sorunları, hiperaktivite, vücudun çeşitli yerlerinde ağrı, anoreksiya veya yeme isteğinde artış.

\subsection{Stresle başa çıkma yöntemleri}

Başa çıkma, en genel anlamda, stresi kontrol etmenin 
ve düzenlemenin bir yoludur. Stres etkenine verilen cevap, olayın fark edilmesiyle başlayıp, başa çıkma tarzlarının kullanılmasıyla sona erer. Stresli olayların veya faktörlerin negatif yansımalarını yok etme amaçlı kişiye özgü başa çıkma tarzlarını hayata geçirmek doğal bir tutumdur. Kişi başa çıkma tarzlarını öğrenme ve yaşantılarla beraber edinir. Her kişinin baş vurduğu başa çıkma tarzı benzersizdir Yılmaz ve Oskay (2015: 100).

Başa çıkma ile ilgili dört süreçten bahsedilmektedir;

- Başa çıma, kişi ve çevresi arasında bir süreç veya devam eden karmaşık etkileşimdir.

- Başa çıkma, yıkımdan çok yönetimle ilgilidir; stres gerçekçi bir bakış açısıyla ele alınır ve her sorunun üstesinden gelinemeyeceği öngörülür Yılmaz ve Oskay (2015: 112).

- Değerlendirmeyle ilgili olarak, bir durum stres etkeni olarak görülüyorsa kişi için zaman içerisinde stres etkeni haline gelir. Bu tanım aynı zamanda değerlendirme kavramını da içermektedir.

- Başa çıkma bir çabadır ve potansiyel olarak stresli hali yönetmek için zihinsel ve davranışsal çabaları içerir.

\subsection{Verilerin analizi}

Araştırmanın verileri, SPSS 25.0 istatistik programı ile analiz edilmiştir. Verilerin normal dağılımını değerlendirmek için çarpıklık ve basıklık değerlerine bakılmıştır. Çarpıklık ve basıklık değerleri -2 ile 2 arasında olması nedeniyle analizler parametrik analizler ile yürütülmüştür. Veriler normal dağıldığg için parametrik testler uygulanmış olup, kişisel değişkenlerin değerlendirilmesinde tanımlayıcı istatistik (frekans analizi) analizleri yapılmıştır.

Araştırma verileri analiz için SPSS yazılımına girilmiştir. Eksik veri olup olmadığ1 kontrol edilmiştir. Kullanılacak analiz türleri araştırma problemlerine göre belirlenmiş ve değişkenler arasındaki ilişkiyi belirlemek amacıyla korelasyon analizi yapılmıştır.

Dikkate alınan bağımsız değişkenlere göre farklılaşma durumunu incelemek için karşılaştırma testleri kullanılmıştır. Normal dağılan verilerde iki değişkenin ortalamaları arasında farklılaşma olup olmadığını saptamak amacıyla t-testi analizi kullanılmıştır.

Çalışmada değişkenler arasındaki ilişkiler Pearson
Çarpım-Moment Korelasyon analizi ile incelenmiştir. Tüm analizler .05 anlamlılık düzeyinde test edilmiştir.

Katılımcıların kişisel özellikleriyle ilgili bilgiler Tablo 1 'de verilmiştir.

Araştırmaya göre \%39.2'si ( $\mathrm{N}=83)$ erkeklerden ve \%60.8'i (N=129) kadınlardan, \%22.2' si (N=47) 18-25 yaş aras1, \%29.7'si (N=63) 26-55 yaş aras1, \%24.1'i (N=51) $36-45$ yaş arası, \%15,1'i ( $\mathrm{N}=32)$ 46-55 yaş arası ve \%9.0' 1 ( $\mathrm{N}=19)$ 18-25 yaş arası, katılımcıların \%40.6'si $(\mathrm{N}=86)$ 18-25 bekar, \%49.11'i (N=104) evli ve \%10.4'ü (N=22) 18-25 boşanmış, katılımcıların \%9.9'u ( $\mathrm{N}=21)$ düşük düzey gelirli, \%59.0'1 ( $\mathrm{N=125)}$ orta düzey gelirli, $\% 26.9^{\prime}$ u (N=57) iyi düzey gelirli ve $\% 4.2^{\prime}$ si $(\mathrm{N}=9)$ çok iyi düzey gelirli, katılımcıların \%15.1'i (N=32) ilköğretim mezunu, \%25.5'i (N=54) lise mezunu, \%48,1'i (N=102) üniversite mezunu ve \%11.3'ü (N=24) yüksek lisans/doktora mezunlardan oluşmaktadır.

Analiz sonuçlarına göre erkeklerde ( $X=94.2000$, $\mathrm{SD}=22.23511)$ ve kadınlarda $(X=85.9474, S D=17.61777)$ Başa Çıkma Tarzları toplam puanları $[\mathrm{t}(128)=2.096) ; \mathrm{p}$ <. 05]. Başka bir deyişle, Erkeklerin Stresle Başa Çıkma Tarzları Ölçeği toplam puanları kadınlara göre anlamlı düzeyde yüksek bulunmuştur.

Tablo 2'de görüldüğü gibi, katılımcıların Stresle Başa Çıkma alt boyutlarından İyimser Yaklaşım verilerine bakıldığında cinsiyete göre belirgin bir farklılık olup olmadığını görmek amacıyla Bağımsız Örneklem t-Testi yapılmıştır. Analiz sonuçlarına bakıldığında iyimser yaklaşım puanları erkekler $(X=16.0000$, $\mathrm{SS}=4.87625)$ ve kadinlar $(\mathrm{X}=11.9474, \mathrm{SS}=4.87625)$ arasinda anlamlı farklılık göstermektedir [ $\mathrm{t}(128)=2.633 ; \mathrm{p}$ $<.05]$. Diğer bir ifadeyle erkeklerin Stresle Başa Çıkma Tarzları Envanteri Tarzları alt boyutlarından iyimser Yaklaşımdan aldıkları toplam puanlar kadınlara kıyasla anlamlı derecede yüksek bulunmuştur.

Tablo 2' de görüldüğü üzere katılımcıların Stresle Başa Çıkma Tarzları alt boyutlarından Kendine Güvenli Yaklaşım, Çaresiz Yaklaşım, Boyun Eğici Yaklaşım ve Sosyal Destek Arama Yaklaşım puanlarının cinsiyet değişkenine göre anlamlı fark olup olmadığını belirlemek için Bağımsız Örneklem t-Testi yapılmıştır. Analiz sonuçlarına göre Stresle Başa Çıkma Tarzları alt boyutlarından Kendine Güvenli, Çaresiz, Boyun Eğici ve Sosyal Destek Arama Yaklaşım puanları erkekler ve kadınlar arasında belirgin farklılık göstermemektedir $(p>0,05)$. 
Tablo 1. Örneklem Grubunun Sosyodemografik Değişkenlere Göre Betimsel Analiz Sonuçları

\begin{tabular}{|c|c|c|c|}
\hline \multicolumn{2}{|c|}{ Değişkenler Gruplar } & \multirow{2}{*}{$\begin{array}{l}\mathbf{n} \\
83\end{array}$} & \multirow{2}{*}{$\begin{array}{l}\mathbf{\%} \\
39.2\end{array}$} \\
\hline \multirow{3}{*}{ Cinsiyet } & Erkek & & \\
\hline & Kadın & 129 & 60.8 \\
\hline & Toplam & 212 & 100.0 \\
\hline \multirow{6}{*}{ Yaş } & $18-25$ & 47 & 22.2 \\
\hline & $26-35$ & 63 & 29.7 \\
\hline & $36-45$ & 51 & 24.1 \\
\hline & $46-55$ & 32 & 15.1 \\
\hline & $56-65$ & 19 & 9.0 \\
\hline & Toplam & 212 & 100.0 \\
\hline \multirow{4}{*}{$\begin{array}{l}\text { Medeni } \\
\text { Durum }\end{array}$} & Bekar & 86 & 40.6 \\
\hline & Evli & 104 & 49.1 \\
\hline & Boşanmış & 22 & 10.4 \\
\hline & Toplam & 212 & 100.0 \\
\hline \multirow{5}{*}{$\begin{array}{l}\text { Gelir } \\
\text { Durumu }\end{array}$} & Düşük & 21 & 9.9 \\
\hline & Orta & 125 & 59.0 \\
\hline & İyi & 57 & 26.9 \\
\hline & Çok iyi & 9 & 4.2 \\
\hline & Toplam & 212 & 100.0 \\
\hline \multirow{5}{*}{ Eğitim } & İlköğretim Mezunu & 32 & 15.1 \\
\hline & Lise mezunu & 54 & 25.5 \\
\hline & Üniversite Mezunu & 102 & 48.1 \\
\hline & Yükseklisans/Doktora & 24 & 11.3 \\
\hline & Toplam & 212 & 100.0 \\
\hline
\end{tabular}

Tablo 2. Stresle Başa Çıkma Tarzları Envanteri ve Alt Boyutlarından Alınan Puanların Cinsiyet Açısından Bağımsız Örneklem t-Testi ile Karşılaştırma Sonuçları

\begin{tabular}{|c|c|c|c|c|c|c|c|}
\hline Bağımlı Değişken & Cinsiyet & n & $\overline{\mathbf{X}}$ & Ss & sd & $\mathbf{t}$ & $\mathbf{p}$ \\
\hline \multirow{2}{*}{$\begin{array}{lr}\text { Stresle } & \text { Başa } \\
\text { Çıkma Tarzları } \\
\text { Envanteri }\end{array}$} & Erkek & 83 & 94.2000 & 22,23511 & \multirow[b]{2}{*}{128} & \multirow[b]{2}{*}{2.096} & \multirow[b]{2}{*}{$.019 *$} \\
\hline & Kadın & 129 & 85.9474 & 17,61777 & & & \\
\hline \multirow{2}{*}{$\begin{array}{l}\text { Kendine Güvenli } \\
\text { Yaklaşım }\end{array}$} & Erkek & 83 & 27.7000 & 8,44656 & \multirow{2}{*}{128} & \multirow{2}{*}{1.320} & \multirow{2}{*}{.198} \\
\hline & Kadın & 129 & 24.3158 & 5,37538 & & & \\
\hline \multirow{3}{*}{$\begin{array}{l}\text { İyimser } \\
\text { Yaklaşım }\end{array}$} & Erkek & 83 & 16.0000 & 4,87625 & \multirow{2}{*}{128} & \multirow{2}{*}{2.633} & \multirow{2}{*}{$.014 *$} \\
\hline & Kadın & 129 & 11.9474 & 3,37431 & & & \\
\hline & Erkek & 83 & 18.0000 & 6,09189 & 128 & -946 & .353 \\
\hline $\begin{array}{l}\text { Çaresiz } \\
\text { Yaklaşım }\end{array}$ & Kadın & 129 & 20.0526 & 5,26491 & & & \\
\hline \multirow{2}{*}{$\begin{array}{l}\text { Boyun } \\
\text { Yaklaşım }\end{array}$} & Erkek & 83 & 14.7000 & 6,36047 & \multirow{2}{*}{128} & \multirow{2}{*}{687} & \multirow{2}{*}{.498} \\
\hline & Kadın & 129 & 13.2632 & 4,77077 & & & \\
\hline \multirow{2}{*}{$\begin{array}{l}\text { Sosyal Destek } \\
\text { Arama } \\
\text { Yaklașım }\end{array}$} & Erkek & 83 & 13.7000 & 3,43350 & \multirow[b]{2}{*}{128} & \multirow[b]{2}{*}{303} & \multirow[b]{2}{*}{.764} \\
\hline & Kadın & 129 & 13.3158 & 3,14559 & & & \\
\hline
\end{tabular}


Tablo 3 analiz sonuçlarına göre, Fagerström Nikotin Bağımlılığ ${ }_{1}$ Testi toplam puanları erkekler $(X=8.2892$, $\mathrm{SD}=1,37513)$ ve kadınlar $(X=7.7674, \mathrm{SD}=1.38356)$ arasinda anlamlı farklılıklar göstermektedir [t(128)= 2.096, p <.05]. Diğer bir deyişle, erkeklerin Fagerström Nikotin Bağımlılığı Testi toplam puanları kadınlarınkinden anlamlı düzeyde yüksek bulunmuştur.

Tablo 4 inceleme sonuçlarına bakıldığında Fagerström Nikotin Bağımlılık Testi toplam puanları yaş faktörüne göre değişkenlik göstermektedir $[F(4,211)=3.654$, $\mathrm{p}<$.05]. Fagerström Nikotin Bağımlılık yaş değişkenine göre anlamlı farkın belirlenmesi için yapılan Tukey testi sonuçlarına göre, 46-55 yaş arası katılımcıların 26-35 yaş arası katılımcılardan Fagerström Nikotin Bağımlılık Testi puanları daha yüksek olduğu bulunmuştur.

Tablo 5' de Katılımcıların Stresle Başa Çıkma Tarzları Envanteri ile Fagerström Nikotin Bağımlılık Testi Puanları arasındaki bağlantıya yönelik Pearson Korelasyon Analizi sonuçları ortaya konmuştur.

Tablo 5'e göre Stresle Başa Çıkma Tarzları Envanteri ile Fagerström Nikotin Bağımlılık Testi puanları arasinda matematiksel olarak anlam ifade eden, yüksek düzeyde ve negatif yönde bir bağlantı saptanmıştır ( $\mathrm{r}=-742, \mathrm{p}<.05)$. Bu bulguya göre katılımciların stresle başa çıkma puanları arttıkça fagerström nikotin bağımlılık puanları azalmaktadır.
Tablo 5 incelendiğinde katılımcıların Stresle Başa Çıkma Tarzları Envanteri alt boyutu kendine güvenli yaklaşım ile Fagerström Nikotin Bağımlılık Testi puanları arasında matematiksel olarak anlam ifade eden, yüksek düzeyde ve negatif yönde bir bağlantı saptanmıştır ( $r=-575, \mathrm{p}<.05)$. Bu bulguya göre katılımcıların kendine güvenli yaklaşım puanı arttıkça fagerström nikotin bağımlılık puanları azalmaktadır.

Tablo 5 incelendiğinde katılımcıların Stresle Başa Çıkma Tarzları Envanteri alt boyutu iyimser yaklaşım ile Fagerström Nikotin Bağımlılık Testi puanları arasında matematiksel olarak anlam ifade eden, yüksek düzeyde ve negatif yönde bir bağlantı saptanmıştır ( $\mathrm{r}=-481$, $\mathrm{p}<.05)$. Bu bulguya göre katılımcıların iyimser yaklaşım puanı arttıkça fagerström nikotin bağımlılık puanları azalmaktadır.

Tablo 5 incelendiğinde katılımcıların Stresle Başa Çıkma Tarzları Envanteri alt boyutu çaresiz yaklaşım ile Fagerström Nikotin Bağımlılık Testi puanları arasında matematiksel olarak anlam ifade eden, yüksek düzeyde ve negatif yönde bir bağlantı saptanmıştır ( $\mathrm{r}=-542$, $\mathrm{p}<.05$ ). Bu bulguya göre katılımcıların çaresiz yaklaşım puanı arttıkça fagerström nikotin bağımlılık puanları azalmaktadır.

Tablo 5 incelendiğinde katılımcıların Stresle Başa Çıkma Tarzları Envanteri alt boyutu boyun eğici yaklaşım ve sosyal destek arama yaklaşımı ile Fagerström Nikotin Bağımlılık Testi puanları arasında matema-

Tablo 3. Fagerström Nikotin Bağımlılık Testi Puanların Cinsiyet Açısından Bağımsız Örneklem t-Testi ile Karşılaştırma Sonuçları

\begin{tabular}{|c|c|c|c|c|c|c|c|}
\hline Bağımlı Değişken & Cinsiyet & $\mathbf{n}$ & $\overline{\mathbf{X}}$ & Ss & sd & $\mathbf{t}$ & p \\
\hline \multirow{2}{*}{$\begin{array}{l}\text { Fagerström } \\
\text { Nikotin } \\
\text { Bağımlılık Testi }\end{array}$} & Erkek & 83 & 8.2892 & 1.37513 & \multirow[b]{2}{*}{212} & \multirow[b]{2}{*}{2.686} & \multirow[b]{2}{*}{$.008 * *$} \\
\hline & Kadın & 129 & 7.7674 & 1.38356 & & & \\
\hline
\end{tabular}

Tablo 4. Fagerström Nikotin Bağımlılık Testi Alınan Puanların Yaş Değişkenine Göre Tek Yönlü Varyans Analizi Karşılaştırma Sonuçları

\begin{tabular}{|c|c|c|c|c|c|c|c|}
\hline $\begin{array}{l}\text { Bağımlı } \\
\text { değişken }\end{array}$ & Gruplar & $\mathbf{n}$ & $\overline{\mathbf{X}}$ & Ss & sd & $\mathbf{F}$ & p \\
\hline \multirow{6}{*}{$\begin{array}{l}\text { Fagerström } \\
\text { Nikotin } \\
\text { Bağımlılık } \\
\text { Testi }\end{array}$} & $18-25$ & 47 & 7,8085 & 1,29612 & \multirow{6}{*}{$\begin{array}{l}4 \\
211\end{array}$} & \multirow{6}{*}{3,654} & \multirow{6}{*}{$.007 * *$} \\
\hline & $26-35$ & 63 & 7,6984 & 1,13073 & & & \\
\hline & $36-45$ & 51 & 7,8039 & 1,51023 & & & \\
\hline & $46-55$ & 31 & 8,5806 & 1,52259 & & & \\
\hline & $56-65$ & 19 & 8,6316 & 1,53516 & & & \\
\hline & Toplam & 211 & 7,9621 & 1,39676 & & & \\
\hline
\end{tabular}

Not. ${ }^{*}{ }^{*} \mathbf{p}<.05,{ }^{*} \mathbf{p}<.01$. 
Tablo 5. Katılımcıların Stresle Başa Çıkma Tarzları Envanteri ile Fagerström Nikotin Bağımlılık Testi Puanları Arasındaki İlişkinin İncelenmesine Dair Pearson Korelasyon Analizi Sonuçları

\begin{tabular}{|c|c|c|}
\hline Değişkenler & $\begin{array}{l}\text { Fagerström } \\
\text { Testi }\end{array}$ & Nikotin Bağımlılık \\
\hline \multirow{3}{*}{$\begin{array}{l}\text { Stresle Başa } \\
\text { Envanteri }\end{array}$} & $-.742^{* *}$ & \\
\hline & .000 & \\
\hline & 29 & \\
\hline \multirow{3}{*}{ Kendine Güvenli Yaklaşım } & $-.575^{* *}$ & \\
\hline & .001 & \\
\hline & 29 & \\
\hline \multirow{6}{*}{ İyimser Yaklaşım } &.$-481^{* *}$ & \\
\hline & .008 & \\
\hline & 29 & \\
\hline &,$-542^{* *}$ & \\
\hline & .002 & \\
\hline & 29 & \\
\hline \multirow{3}{*}{ Boyun Eğici Yaklaşım } &.-355 & \\
\hline & .059 & \\
\hline & 29 & \\
\hline \multirow{3}{*}{ Sosyal Destek Arama Yaklaşım } & .112 & \\
\hline & .234 & \\
\hline & 29 & \\
\hline
\end{tabular}

Not. $* * \mathbf{p}<.05, * \mathbf{p}<.01$.

tiksel olarak anlamlı bir ilişki olduğu belirlenmemiştir $(\mathrm{p}>.05)$.

\section{TARTIŞMA VE YORUM}

Araştırmada stresle başa çıkma tarzları envanteri ve alt boyutlarından alınan puanların cinsiyet açısından incelendiğinde, Stresle Başa Çıkma Tarzları toplam ve alt boyutlarından iyimser yaklaşım puanları erkekler ve kadınlar arasında anlamlı farklılık saptanmıştır. Erkeklerin Stresle Başa Çıkma Tarzları Envanterinden aldıkları toplam puanlar kadınlardan daha yüksek olduğu görülmüştür. Diğer taraftan farklı çalışmalarda stresle başa çıkmada cinsiyet etkeninin anlamlı bir farklılık yaratmadığını ancak kızların erkeklere göre başa çıkmada duygu odaklı yöntemleri daha fazla kullandıklarını belirlemiştir Bulut (2005: 467).

Araştırmada stresle başa çıkma tarzları envanteri ve alt boyutlarından alınan puanlar yaş açısından incelendiğinde, Stresle Başa Çıkma Tarzları ölçeği yaş değişkenine göre anlamlı farklılık saptanmıştır. 26-35 yaş arası katılımcıların 56-65 yaş arası katılımcılardan Stresle Başa Çıkma Tarzları puanları daha yüksek olduğu bulunmuştur. Stresle başa çıkma yöntemlerinin ve alt boyutlarının yaşa göre farklılaşma gösterip gös- termediğini ortaya çıkarmak amacıyla yapılan ANOVA testi sonucunda, stresle başa çıkma yöntemlerinin değiştiği tespit edilmiştir. Stresli ve özgüvenli yaklaşım alt boyutları ise 31-37 ve 24-30 yaşları arasında yer almıştır. Farkın 31-37 yaş kitlesi için daha olumlu sonuçları görülmüştür. Katılımcıların boyun eğici yaklaşım stillerinin yaşa göre iyimser yaklaşım stilindeki farkın 31-37 ve 24-30 yaş grupları arasında olduğu ve farkın 31-37 yaş grubu lehine olduğu görülmüştür Biber ve diğ. (2019: 32). Bu sonuçlar 40 yaşın altı katılımcıların stresle uğraşırken daha sağlıklı yaklaşımlar sergiledikleri, dirençli, güçlü, öncelikle özgüvenli, sakin ve stres kaynaklarına karşı iyimser oldukları, 40 yaş sonrası olanların itaatkar bir yaklaşım sergiledikleri, mücadeleden vazgeçtikleri, stres kaynaklarına kaderci bir şekilde yaklaştıkları, çözüm için çaba göstermediklerini strese karşı dirençlerini kaybettikleri şeklinde yorumlanabilir Biber, ve diğ. (2019). Diğer taraftan yaş artışının psikiyatri kliniklerine başvuruyu arttıran faktörlerden biri olduğu da gösterilmiştir Kaya ve diğ. (2007). Bu nedenle yaş artışıyla birlikte stresle başa çıkma becerilerinin düştügünü göstermektedir. Bu çalışmanın sonucu iyimser yaklaşım ve boyun eğici yaklaşım boyutu hariç araştırmalarla paralellik göstermektedir. 
Araştırmada Fagerström Nikotin Bağımlılık Testi alınan puanlar cinsiyet değişkeni açısından incelendiğinde, çıkan sonuçlarda Fagerström Nikotin Bağımlılık Testi puanları erkekler ve kadınlar arasında anlamlı farklılık göstermektedir. Erkeklerin Fagerström Nikotin Bağımlılık Testi puanları kadınlara kıyasla belirgin derecede daha fazla olduğu görülmüştür. Yapılan çalışmada sigara içenlerin cinsiyet dağılımı değerlendirildiğinde, erkeklerin yaklaşık olarak kadınlardan 3 kat daha fazla sigara kullandığı tespit edilmiştir Çelepkolu ve diğ. (2014: 712). Baykan ve Naçar (2014: 483) yaptıkları çalışmada erkeklerin kızlara göre yaklaşık 6 kat daha fazla sigara içtiğini bulmuşlardır. Eğitim kurumunda çalışanların da toplumdaki genel dağılımla uyumlu sonuç gösterdiği yani erkek çalışanların sigara içme oranı daha yüksek çıktığı gözlenmiştir.

Araştırmada Fagerström Nikotin Bağımlılık Testi alınan puanların yaş değişkeni açısından incelendiğinde, Fagerström Nikotin Bağımlılık yaş değişkenine göre anlamlı farkın belirlenmesi için yapılan Tukey testi sonuçlarına göre, 46-55 yaş arası katılımcıların 26-35 yaş arası katılımcılardan Fagerström Nikotin Bağımlılık Testi puanları daha yüksek olduğu bulunmuştur. Literatüre bakıldığında nikotine bağımlılık seviyesinin yaşla birlikte arttığı görülmüştür Okutan ve diğ. (2007: 356). Yapılan bir başka çalışmada yaşlı kişilerde gençlere nazaran nikotin bağımlılık düzeylerinin yüksek olduğu tespit edilmiştir Yakar ve Pirinççi (2019: 65).

Araştırmada Stresle Başa Çıkma Tarzları Envanteri ve alt boyutları Kendine Güvenli Yaklaşım, İyimser Yaklaşım ve Çaresiz Yaklaşım ile Fagerström Nikotin Bağımlılık Testi puanları arasında istatistiksel olarak anlamlı negatif yönlü bir ilişki olduğu belirlenmiştir. Eğitim kurumlarında çalışan katılımcıların stresle başa çıkma puanları arttıkça fagerström nikotin bağımlılık puanları azalmaktadır.

Sigara kullanan ve stresle başa çıkmada zorlanan kişilerin yaşamın zor olduğunu düşündüğü ve sorunları çözmek yerine anlık çözüm sağlayan sigara gibi maddelere başvurdukları görülmektedir Koçhan ve İlhan (2015: 61).

\section{5. ÖNERILER}

Araştırmada elde edilen bulgulara göre Stresle Başa Çıkma Tarzları Envanteri ve alt boyutları ile Fagerström Nikotin Bağımlılık Testi puanları arasında istatistiksel olarak önemli negatif yönde bir ilişki ol- duğu belirlenmiştir. Bu sonuca dayanarak özellikle Stresle Başa Çıkma Tarzları Envanteri alt boyutları ve stres ile başa çıkma becerilerinin geliştirilmesine yönelik bilgilendirme ve eğitim düzenlenmesi önerilir. Özellikle sigara içme davranışının olumsuz durumları göz önüne alındığında farkındalık ve bilinçlendirme çalışmaları bedensel ve ruhsal bozukluklardan korunabilmeleri açısından büyük önem taşımaktadır.

Araştırmada Erkeklerin Stresle Başa Çıkma Tarzları Envanterinden aldıkları toplam puanlar kadınlardan daha yüksek çıkmıştır. Bu sonuca göre toplumsal cinsiyet kavramından etkilenerek, toplumda kadın erkek eşitliğini sağlamaya yönelik çalışmaların, yine erkek ve kız çocukların yetiştirilme biçimlerinin bu anlamda değişmesinin öneminin anlatılması, bu sayede kadınların kendilerini olduğu haliyle kabul edebilme kapasitelerinin geliştirilebileceği ve bunun sadece kadınlar için değil genel olarak toplum ruh sağllğına olumlu katkıları olacağ1 düşünülmektedir.

Araştırmada 26-35 yaş arası katılımcıların 56-65 yaş arası katılımcılara göre Stresle Başa Çıkma Tarzları puanları daha yüksek olduğu bulunmuştur. Bu bağlamda yaş ilerledikçe stresle başa çıkma azalmaktadır. Bu durum ileriki yaşlarda da stresle başa çıkma becerilerinin geliştirilmesine yönelik uygulamalara daha yaşlı katılımcıların da dahil edilmesi önerilir.

Araştırmada bekar katılımcıların evli katılımcılardan Stresle Başa Çıkma Tarzları puanları daha yüksek olduğu bulunmuştur. Bu nedenle evli kişilere yönelik iş yükünün azalması ve firsat buldukça kendilerine yönelik stres faktörlerinden uzak durarak daha fazla stresle başa çıma becerilerini geliştirmelerine yönelik etkinliklere katılmaları önerilir.

Özellikle kamu ve özel sektör kurumları sorumlularına, bazı dönemlerde Stresle Başa Çıkma Tarzları, yönetimsel olarak kurum stratejilerini revize etmeleri, çalışma ve görev sorumluluğu çerçevesinde görev tanımı çalışmaları önerilmektedir. Eğitim kurumlarının ve yöneticilerinin stresle başa çıkmada önemli bir faktör olduğu görülmektedir. Bu nedenle stresle başa çıkmada eğitim kurumu çalışanlarının ve eğitimcilerin üst düzeyde eğitim almaları, revizyonların kısa aralıklarla yapılması stresle başa çıkmada fayda ve verimlilik sağlayan stratejilerin çeşitliliği, özerklik ve yönetimsel özelliklerinin ağırlıklarının toplumsal değerlere göre artırılması, kısa, orta ve belirlenen diğer dönemlere göre stresle başa çıkmada bazı ölçümlerin 
ve testlerin yapılması önerilmektedir.

Araştırmada yüksek lisans/doktora mezunu katılımc1ların lise ve ilköğretim mezunu katılımcılardan Stresle Başa Çıkma Tarzları puanları daha yüksek olduğu bulunmuştur. Bu bağlamda eğitim düzeyinin stresle başa çıkmada önemli bir faktör olduğu görülmektedir ve bireylerin sadece orta düzeyde değil daha fazla olanaklar dahilinde eğitim almaları önerilir.

Araştırmada erkeklerin Fagerström Nikotin Bağıml1lık Testi toplam puanları kadınlara kıyasla anlamlı derecede yüksek bulunmuştur. Bu bağlamda sigaranın zararları ve etkilerine yönelik eğitim ve seminerlere erkeklerin daha fazla katılmaları ve gerekirse sigara bağımlılığı ile ilgili tedavi almaları önerilir.

Genel olarak günümüzde stres, sigara ve kaygı ile başa çıkma konusunda bilgiler arttıkça, insanlar bu tür durumlarda bilinçlenecek ve daha otokontrollü olabileceklerdir. Mevcut kamu hizmeti duyurularının arttırılması ve iyileştirilmesi, sosyal öğrenmeyi önlemek amacıyla çocukların olduğu ortamlarda sigara kullanımının en aza indirilmesi, dumansız hava alanlarının fazlalaştırılması, stres ve stresle başa çıkma yolları olarak herkesin kolayca ulaşabileceği bilgilendirici seminerler yapılması önemlidir. Sigara bağımlılığıyla kişi tek başına başa çıkamıyorsa bu konuda bir uzmandan destek alması ve yapıcı başa çıkma metotlarını öğrenerek yaşamda uygulaması sağlanabilir.

Araştırma sonucunda elde ettiğimiz veriler sınırlılıkların varlığıyla değerlendirilmelidir. Örneklem sayısının bütünü yansıtmaması sonuçların genellenebilirliğini kısıtlamaktadır. Buna ilaveten katılımcılar ile yüz yüze görüşme yapılamamış, veriler çevrimiçi ortamda elde edilerek incelenmiştir. Çevrimiçi ortamda elde edilen veriler araştırmada elde edilen bilgilerin ve çıkan sonuçların güvenilirliğini etkileyebilecek bir unsur olabileceği düşünülmektedir. Son olarak araştırmanın sonuçlarının desteklenmesi açısından yeni araştırmalar gerekmektedir. Daha fazla katılımcıyla ve yüz yüze görüşülerek yapılacak yeni araştırmalar, sigara içen ve içmeyenlerin katılacağı̆, sigara ve diğer madde kullanıcılarının da dahil olacağı yeni çalışmalar gerekmektedir.

\section{KAYNAKÇA}

BAL, F. (2019). Şema terapinin sigarayı bırakma davranışı üzerindeki etkisinin incelenmesi. Avrasya Sosyal ve Ekonomi Araştırmaları Dergisi, 6(1), 187-199.

BASUT, E. (2006). Stres, başa çıkma ve ergenlik. Çocuk ve Gençlik Ruh Sağlı̆̆ Dergisi, 13(1),31-36.

BAYKAN, Z. \& NAÇAR, M. (2014). Tıp fakültesi öğrencilerinin sigara kullanımı ve tütün kanununa ilişkin görüşleri. Dicle Tip Dergisi,41(3),483-490.

BİBER, K., CANKORUR, H., AYDEMIR, E. A. VE GÜLER, R. S. (2019). Okul öncesi öğretmen ve öğretmen adaylarının stresle başa çıkma tarzları. Uşak Üniversitesi Eğitim Araştırmaları Dergisi, 5(2), 32-62.

BULUT, N. (2005). İlköğretim öğretmenlerinde, stres yaratan yaşam olayları ve stresle başa çıkma tarzlarının çeşitli değişkenlerle ilişkisi, Kastamonu Eğitim Dergisi, 13(2), 467-478.

ÇElePKOlU, T., ATLI, A., PALANCI, Y., YILMAZ, A., DEMIR, S., İBİLOĞLU, A. O. \& EKİN, S. (2014). Sigara kullanıcılarda nikotin bağımlılık düzeyinin yaş ve cinsiyetle ilişkisi: Diyarbakır örneklemi. Dicle Tip Dergisi, 41(4), 712-716

DEMIR, T., TUTLUOĞLU, B., KOÇ, N. \& BILlGiN, L. (2004). Sigara b1rakma polikliniğimizin bir yıllık izlem sonuçları. Tüberküloz ve Toraks Dergisi, 52(1), 63-68.

FOLKMAN, S. \& LAZARUS, R.S. (1986). Appraisal, coping, health status and psychological symptoms. J Pers Soc Psychol, 50,571-579.

FROYEN, A. (1988). Classroom management. Ohio: Merrill Publishingi Company.

GÖKLER, R. (2012). Modern çağın hastalığı; stres ve etkileri/the disease of modern era; stress and its effects. Journal of History Culture and Art Research, 1(3), 154-168.

GRAHAM, H. (1999). Stresi kendi yararınıza kullanın. İstanbul: Alfa Yayınları.

IVANCEVICH, J. M., MATTESON, M. T. \& KONOPASKE, R. (1990). Organizational behavior and management

KAYA, M., GENÇ, M., KAYA, B., \& PEHLIVAN, E. (2007). Tıp fakültesi ve sağlık yüksekokulu öğrencilerinde depresif belirti yaygınlığı, stresle başa çıkma tarzları ve etkileyen faktörler. Türk Psikiyatri Dergisi, 18(2), 137-146. KETEN, H. S., KAHRAMAN, H., ÜÇER, H., ÇELIK, M., SUCAKLI, M. H. \& ERSOY, Ö. (2014). Aile hekimlerinin sigara bağımlılığı tedavisi konusundaki bilgi, tutum ve uygulamaları. Türkiye Aile Hekimliği Dergisi, 18(2), $58-62$.

KOÇHAN, K. \& İLHAN, T. (2015). Erbaş/Erlerin Ebeveyne Bağlanma Stilleri, Depresyon Düzeyleri ve Stresle Başa Çıkma Stillerinin Madde Kullanımı Açısından İncelenmesi. Addicta: The Turkish Journal on Addictions, 2(2), 61-109.

KRAAIIJ, V., GARNEFSKI, N. \& MAES, S. (2002). The joint effects of stress, coping, and coping resources on depressive symptoms in elderly. Anxiety Stress Coping, 15,163.

Okutan, O., Taş, D., Kaya, H. ve Kartaloğlu, Z. (2007). Sigara içen sağllk personelinde nikotin bağımlılık düzeyini etkileyen faktörler. Tüberküloz ve Toraks Dergisi, 55(4), 356-363.

ÖZARSLAN, Z., FISTIKÇI, N., KEYVAN, A., UĞURAD, Z. I. \& SAYGILI, S. (2013). Depresyon hastalarının stres ile başa çıkma stratejileri. Marmara Medical Journal, 26,130-5.

SCHERMERON, R. J. (1989). Management For Productuvity. New York.

SELYE, H. (1974). Stress without distress. NY: J.B.Lippincott.

SELYE, H. (1976). Stress in health and disease. Boston: Butterworths.

WERDEN, E. M. (2001). Religious identity as a coping resource. Miami University.

YAKAR, B. ve Pirinççi, E. (2019). Bir üniversite hastanesi polikliniğine 
başvuran hastaların sigara ve alkol bağımlılık düzeylerine etki eden faktörler. Kahramanmaraş Sütçü İmam Üniversitesi Tıp Fakültesi Dergisi, 14(2), 57-65.

YILMAZ, T. \& OSKAY, Ü. Y. (2015). İnfertilite stresi ile başa çıkma yöntemleri ve hemşirelik yaklaşımları. Sağlık Bilimleri ve Meslekleri Dergisi, 2(1), 100-112. 